\title{
THE COMING OF THE NEW DISSENT: THE SUPREME COURT, 1942-43
}

\author{
C. Herman Pritchetr*
}

CCORDING to an interesting analysis by Professor John T. Ganoe in
the Oregon Law Review, the recent history of the Supreme Court
has been marked by "the passing of the old dissent." He suggests that "Not since the days of John Marshall has the court been so constituted to bring about, in all essential economic and political matters, constant and continuous unanimity." But that has happened, he believes, on the present Roosevelt-appointed court. He continues:

On the whole no other President has been able to make of the court such a harmonious body since the time of Washington. Jackson, by the appointment of Taney and four associate justices, all democrats, merely brought in a liberal majority to counterbalance and qualify the work of Marshall's court. Neither Lincoln nor Taft appointed justices of a similar character, or for that matter even of the same party affiliation. To Roosevelt, then, goes the credit of establishing a court that is distinctly unique-a court virtually without dissent on the old fundamental issues of government and economic life. ${ }^{2}$

Professor Ganoe qualifies these assertions, however, by adding: "This is not to say, of course, that dissent has entirely disappeared for the statistics of the court decisions since the Roosevelt reorganization would belie that." They certainly would, and do. The statistics show, in fact, that from a quantitative point of view at least, the reorganized Supreme Court has become by far the most badly divided body in the history of that institution. President Roosevelt's first appointees to the Court took their seats during the $1937-38$ term. For the six terms preceding (i.e., from the I93I-32 term through the I936-37 term), there were dissents to 16 per cent of all the full opinions written by the Court. ${ }^{3}$ During the six terms of

* Assistant Professor of Political Science, The University of Chicago.

I The Passing of the Old Dissent, 2x Oregon Law Rev. 285 at 297 (I942).

2 Ibid., p. 288.

${ }^{3}$ Several points need explanation in connection with these figures on dissents. The count of opinions includes all full opinions plus per curiam decisions reported in the same manner as full opinions. Opinions are counted, not cases; often several cases are decided by a single opinion. "Companion cases" (cases involving an issue identical with that settled in a preceding decision and requiring little or no new discussion) are counted, since they are separate decisions, though this may have the effect of giving double weight to divisions of opinion over a single issue. Occasionally it is not clear whether a justice who writes a separate opinion in a case is 
the reorganized Court (I937-38 through I942-43), the figure on dissents was 33 per cent-over twice as great. Moreover, the curve of dissent has shown a consistent upward trend during that period. For the term beginning in r93o, only ro per cent of the decisions involved dissent, and for the I935 term the figure was 16 per cent, while in I940 there was a jump to 28 per cent, in I94I to 36 per cent, and for the 1942 term the figure is 44 per cent. Another way of describing the situation is to note that during the six years before reorganization the justices cast an average of 68 dis-

TABLE. 1

NONUNANIMOUS OPINIONS AND DISSENTING VOTES ON THE SUPREME COURT, BY TERMS, I930-42

\begin{tabular}{|c|c|c|c|c|}
\hline \multirow{2}{*}{ TERAr } & \multirow{2}{*}{$\begin{array}{l}\text { TOTAL } \\
\text { OpINIONS }\end{array}$} & \multicolumn{2}{|c|}{$\begin{array}{l}\text { NONONANIMOUS } \\
\text { OPINIONS }\end{array}$} & \multirow{2}{*}{$\begin{array}{l}\text { Dissenting } \\
\text { Votes Cast }\end{array}$} \\
\hline & & Number & Per Cent & \\
\hline 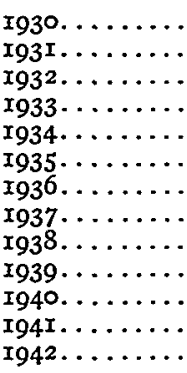 & $\begin{array}{l}x 63 \\
151 \\
169 \\
166 \\
172 \\
160 \\
162 \\
170 \\
149 \\
14 x \\
169 \\
I 62 \\
I 71\end{array}$ & $\begin{array}{l}17 \\
26 \\
27 \\
27 \\
22 \\
26 \\
31 \\
46 \\
50 \\
42 \\
47 \\
59 \\
75\end{array}$ & $\begin{array}{l}\text { Io } \\
\text { I7 } \\
\text { I6 } \\
\text { I6 } \\
\text { I3 } \\
\text { I6 } \\
\text { I9 } \\
27 \\
34 \\
30 \\
28 \\
36 \\
44\end{array}$ & $\begin{array}{r}44 \\
55 \\
61 \\
66 \\
61 \\
80 \\
82 \\
88 \\
116 \\
85 \\
117 \\
160 \\
176\end{array}$ \\
\hline
\end{tabular}

senting votes per term, whereas for the six years since reorganization began the average has been I 24 each term. These data are presented more fully in Table $\mathrm{I}$.

Opinions may differ as to the significance of this aspect of the Supreme Court's behavior, but certainly such a marked increase in judicial disagreement is a subject worthy of investigation, particularly since it seems to indicate a situation just the opposite of that anticipated by competent observers. The present study is limited primarily to an examination of judicial dissent during the most recent term of the Court, that for I94243 (hereafter referred to as the 1942 term). ${ }^{4}$

concurring or dissenting. The rule followed here has been to treat such opinions as dissents when they would require, if followed, a different disposition of the case than was made by the majority.

4 The author has analyzed the record of dissents on the Supreme Court from the I931 through the I94I terms in three previous articles: Divisions of Opinion among Justices of the 
During the 1942 term dissent on the Supreme Court reached an all-time high. Of the I7I full opinions written, dissent was registered to 75 . Ten of these dissents involved a five to four vote, ${ }^{5}$ while three judges dissented in 27 cases, $I 7$ were two-judge dissents, and $2 x$ involved dissents by a single judge. The dissenting records of the individual members of the Court are given in Table 2. It will be noted that every member of the Court, with the exception of the newest member, Mr. Justice Rutledge, had objections to a substantial number of the Court's decisions, the percentages ranging from I8 per cent for Roberts and I 7 per cent for Murphy, down to 9 per cent for Chief Justice Stone.

TABLE 2

PARTICIPATION OF SUPREME COURT JUSTICES IN DISSENTING OPINIONS, I942 TERM

\begin{tabular}{|c|c|c|c|}
\hline Justice & $\begin{array}{l}\text { Number } \\
\text { Dissents }\end{array}$ & $\begin{array}{l}\text { Opinions Par- } \\
\text { ticipated in }\end{array}$ & $\begin{array}{l}\text { Per Cent } \\
\text { Dissents }\end{array}$ \\
\hline 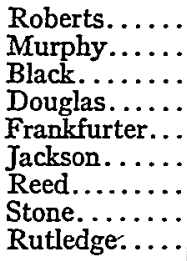 & $\begin{array}{r}3 I \\
26 \\
24 \\
23 \\
2 I \\
I_{7} \\
I_{7} \\
I_{5} \\
2\end{array}$ & $\begin{array}{l}169 \\
152 \\
168 \\
169 \\
171 \\
161 \\
170 \\
x 70 \\
61\end{array}$ & $\begin{array}{l}\text { I8 } \\
\text { I7 } \\
\text { I4 } \\
\text { I4 } \\
\text { I2 } \\
\text { II } \\
\text { IO } \\
9 \\
3\end{array}$ \\
\hline
\end{tabular}

Examination of the record of previous terms shows that it is most unusual for so many members of the Court to file dissents so often. That it is a situation which has developed during the past two terms is demonstrated by Table 3, which gives the dissenting records of the present members of the Court over the past four terms. The tendency in the case of each justice has been a steady increase in the percentage of decisions disagreed to, except for Roberts, who was consistently high during the entire period, and Stone and Douglas, whose rates of dissent dropped in 1942.

For further enlightenment on judicial dissent and its meaning, it is necessary to turn from the records of the individual justices, and to inquire into the relationships between the justices in their dissenting votes.

U.S. Supreme Court, I939-I94I, 35 Am. Pol. Sci. Rev. 890-98 (r94r); The Voting Behavior of the Supreme Court, I941-42, 4 Jour. Pol. 49I-506 (1942); and Ten Years of Supreme Court Voting, 24 Southwestern Soc. Sci. Q. I2-22 (1943).

5 The number of five to four decisions possible was limited because for the greater part of the term there were only eight justices on the Court. Justice Rutledge participated in only about one-third of the term's decisions. 
The most meaningful and graphic method of depicting these relationships has been found to be the type of presentation used in Table 4. The table, covering the 1942 term, indicates for each justice the number of dissents registered, the other members of the Court who agreed with him in his dissents, and the number of times they did so. Dissents in which only a single justice participated are given in parentheses.

This table furnishes a method for discovering the alignments on the present Court, at least as far as the votes of dissenters are concerned. A fairly definite pattern emerges from Table 4. Justices Black, Douglas, and Murphy constitute a bloc on one side of the Court, as evidenced by the fact that they so often dissented in company with one another and so sel-

TABLE 3

PARTICIPATION OF SUPREME COURT JUSTICES IN DISSENTING OPINIONS, I939-r942 TERMS

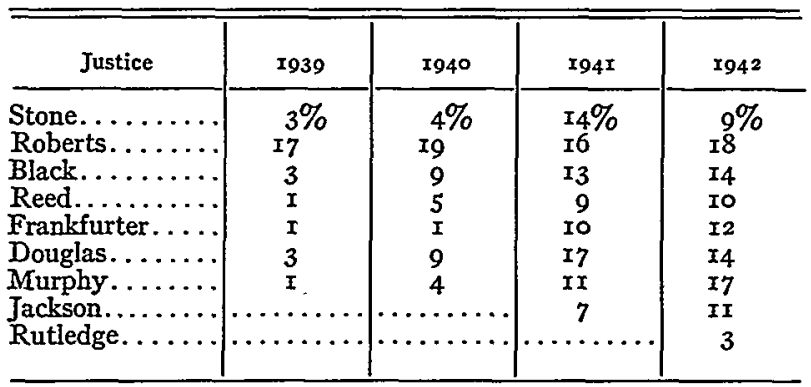

dom dissented in company with the other members of the Court. Justices Stone, Jackson, Reed, Frankfurter, and Roberts constitute a less definite bloc on the other side of the Court. The affinity between certain members of this group appears to be rather marked, while in others the relationship is much less close. On the whole, however, the table demonstrates that it is possible to speak not only about the intensity of judicial dissent, but also about the direction of dissent. Each justice tends to locate himself by his dissents on one side or the other of the normal majority position of the Court, and is consistently much more likely to dissent in company with justices on his side of the Court than in company with those on the opposite side. The members of the Court thus tend to form themselves by their dissents into two wings, which can be referred to conveniently as left and right, though without necessarily using these terms with their ordinary political connotations. In addition, there may be members of the Court who dissent very seldom, as in the case of Rutledge during the I 942 term, or who dissent almost equally in company with members of both 
wings. Justices in this category are clearly to be regarded as in the center of the Court.

As a matter of fact, this typical division of the Court into a left, center, and right has been less clearly defined during the I $94 \mathrm{I}$ and I 942 terms than

TABLE 4

PARTICIPATION OF AND AGREEMENTS AMONG

SUPREME COURT JUSTICES IN DISSENTING

OPINIONS, I942 TERM

\begin{tabular}{|c|c|c|c|c|c|c|c|c|c|c|}
\hline Justice & $\begin{array}{c}\text { No. of } \\
\text { Dis- } \\
\text { sents }\end{array}$ & Black & $\begin{array}{c}\text { Doug- } \\
\text { las }\end{array}$ & $\begin{array}{l}\text { Mur- } \\
\text { phy }\end{array}$ & $\begin{array}{l}\text { Rut- } \\
\text { ledge }\end{array}$ & Stone & $\begin{array}{l}\text { Jack- } \\
\text { son }\end{array}$ & Reed & $\begin{array}{l}\text { Frank- } \\
\text { furter }\end{array}$ & Roberts \\
\hline 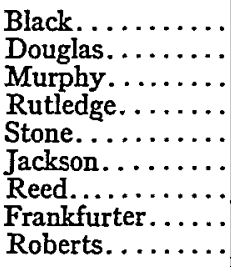 & $\begin{array}{r}24 \\
23 \\
26 \\
2 \\
15 \\
17 \\
17 \\
21 \\
3 I\end{array}$ & $\begin{array}{c}(3) \\
20 \\
16 \\
I \\
I \\
I \\
2\end{array}$ & $\begin{array}{c}20 \\
\ldots \ldots \\
16 \\
I \\
I \\
I \\
I \\
2 \\
I\end{array}$ & $\begin{array}{c}16 \\
I 6 \\
(I) \\
I \\
3 \\
3 \\
2 \\
3 \\
3\end{array}$ & $\begin{array}{c}I \\
I \\
I \\
\ldots\end{array}$ & $\begin{array}{c}\mathrm{Y} \\
\mathrm{I} \\
3 \\
(3) \\
4 \\
4 \\
7 \\
\text { 10 }\end{array}$ & $\begin{array}{l}I \\
I \\
3 \\
\\
4 \\
(3) \\
6 \\
6 \\
8\end{array}$ & $\begin{array}{l}2 \\
1 \\
2 \\
\\
4 \\
6 \\
(2) \\
10 \\
10\end{array}$ & $\begin{array}{r}2 \\
3 \\
1 \\
7 \\
6 \\
\text { I0 } \\
\cdots \\
\text { I4 }\end{array}$ & $\begin{array}{r}\text { I } \\
\mathbf{I} \\
3 \\
\mathbf{I} \\
\text { I0 } \\
8 \\
\text { I0 } \\
\text { I4 } \\
(9)\end{array}$ \\
\hline
\end{tabular}

TABLE 5

PARTICIPATION OF AND AGREEMENTS AMONG

SUPREME COURT JUSTICES IN DISSENTING

OPINIONS, I939 TERM

\begin{tabular}{|c|c|c|c|c|c|c|c|c|c|c|}
\hline Justice & $\begin{array}{c}\text { No. of } \\
\text { Dis- } \\
\text { sents }\end{array}$ & $\begin{array}{c}\text { Doug- } \\
\text { las }\end{array}$ & Black & $\begin{array}{l}\text { Frank- } \\
\text { furter }\end{array}$ & $\begin{array}{l}\text { Mur- } \\
\text { phy }\end{array}$ & Reed & Stone & Hughes & $\begin{array}{l}\text { Rob- } \\
\text { erts }\end{array}$ & $\begin{array}{c}\text { McRey- } \\
\text { nolds }\end{array}$ \\
\hline 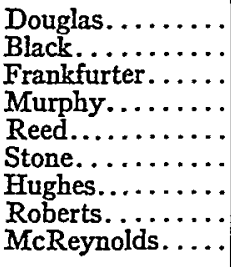 & $\begin{array}{r}4 \\
4 \\
2 \\
I \\
I \\
4 \\
14 \\
23 \\
32\end{array}$ & $\begin{array}{c}4 \\
2 \\
I\end{array}$ & $\begin{array}{c}4 \\
\cdots \\
2 \\
1\end{array}$ & $\begin{array}{l}2 \\
2 \\
\ldots .\end{array}$ & $\cdots \cdots$ & (I) & $\begin{array}{c}(\mathrm{r}) \\
3 \\
3 \\
2\end{array}$ & $\begin{array}{c}3 \\
\ldots \ldots \\
\text { I4 } \\
\text { I2 }\end{array}$ & $\begin{array}{l}3 \\
r 4 \\
(2) \\
\text { I9 }\end{array}$ & $\begin{array}{r}2 \\
12 \\
\text { I9 } \\
\text { (13) }\end{array}$ \\
\hline
\end{tabular}

was customary during the preceding decade. Table 4 makes an interesting contrast with Table 5, which records judicial dissents during the I939 term. During that period, it will be noted, the division between the two wings was perfectly maintained. No justice in one group ever joined in a dissenting opinion with a justice from the other wing. There is another contrast to be noted between the 1939 and 1942 situations; during the I939 term practically all the dissent came from the right-wing group, 
whereas during the I 942 term objections to decisions were filed almost equally from the two wings.

Charts of the type just used are not entirely adequate to reveal fully the alignments on the Court. They give only the interrelationships of the minority group in each disputed decision, and do not show in any positive way the affiliations among the judges who were in the majority in these cases. For example, Table 4 gives little real information concerning the position of Mr. Justice Rutledge, for he dissented so seldom; it is not possible to tell whether his majority voting was predominantly with the left or right wings. Table 6 makes a different and fuller presentation of the

TABLE 6

AGREEMENTS AMONG SUPREME COURT JUSTICES IN NONUNANIMOUS OPINIONS, I942 TERM

(In Percentages)

\begin{tabular}{|c|c|c|c|c|c|c|c|c|c|}
\hline Justice & Black & $\begin{array}{c}\text { Doug- } \\
\text { las }\end{array}$ & $\begin{array}{c}\text { Mur- } \\
\text { phy }\end{array}$ & $\begin{array}{l}\text { Rut- } \\
\text { ledge }\end{array}$ & Stone & $\begin{array}{c}\text { Jack- } \\
\text { son }\end{array}$ & Reed & $\begin{array}{l}\text { Frank- } \\
\text { furter }\end{array}$ & Roberts \\
\hline 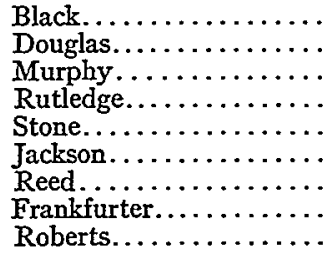 & $\begin{array}{l}\cdots \\
93 \\
73 \\
84 \\
50 \\
46 \\
5 \circ \\
4 x \\
27\end{array}$ & $\begin{array}{l}93 \\
77 \\
87 \\
51 \\
47 \\
50 \\
46 \\
29\end{array}$ & $\begin{array}{l}73 \\
77 \\
\dddot{76} \\
48 \\
47 \\
42 \\
42 \\
29\end{array}$ & $\begin{array}{l}84 \\
87 \\
76 \\
\cdots \\
55 \\
63 \\
55 \\
55 \\
33\end{array}$ & $\begin{array}{l}50 \\
5 I \\
48 \\
55 \\
\because \\
67 \\
68 \\
68 \\
62\end{array}$ & $\begin{array}{r}46 \\
47 \\
47 \\
63 \\
67 \\
\ldots \ldots \\
70 \\
64 \\
57\end{array}$ & $\begin{array}{l}50 \\
50 \\
42 \\
55 \\
68 \\
70 \\
76 \\
76 \\
62\end{array}$ & $\begin{array}{l}4 \mathrm{I} \\
46 \\
42 \\
55 \\
68 \\
64 \\
76 \\
\cdots \\
65\end{array}$ & $\begin{array}{l}27 \\
29 \\
29 \\
33 \\
62 \\
57 \\
62 \\
65 \\
\ldots \ldots\end{array}$ \\
\hline
\end{tabular}

data on alignments, taking into account the agreements between every pair of justices (whether on the majority or minority side) in every nonunanimous decision in which both participated, and showing in percentages the extent of agreement between them. For example, during the r942 term Roberts and Jackson were both participants in 68 of the 75 opinions where there was disagreement. In 39 of these decisions they were on the same side, and in the other 29 they were on opposite sides. Thus the table shows the rate of agreement between them to be 57 per cent. The same data are given for every other pair of justices.

While on the whole Table 6 confirms the picture presented by Table 4, it presents the relationships more clearly and accurately. It calls attention to the closeness of the ties between Black and Douglas, who agreed in 93 per cent of the decisions. It shows that Rutledge is much more closely affliated with the left-wing group than would have been guessed from the previous table. Murphy is the least consistent member of the left wing, judged by his rates of agreement with the other three justices, 
but this four-member group on the left is fairly cohesive, the rates of agreement therein ranging from 73 to 93 per cent.

The other five justices on the Court may be spoken of as the right wing, though the rates of agreement among them, ranging from 57 to 76 per cent, are much lower than those of the left-wing group. If Mr. Justice Roberts is eliminated, the remaining four justices on the right constitute a somewhat more cohesive bloc, rates of agreement ranging from 64 to 76 per cent. The closest relationship in this group is that between Frankfurter and Reed.

These tables make clear the alignments on the Court, but do nothing in the way of explaining them. It is difficult enough, of course, to "explain" any human action, even with the most complete data, so that there are obvious limits" on what can be done in accounting for judicial voting behavior with only written opinions to form the basis for the analysis. But one feasible approach to the problem is to examine the relationship between the votes of the justices and the kinds of issues raised in the cases where dissenting votes were cast.

For the purpose of this examination it will be assumed that cases coming to the Supreme Court can be divided into two categories-"public policy" and "purely legal." In the former class fall those cases which by reason of their subject matter offer an opportunity for the decision to be influenced by judicial views as to desirable public policy. The "purely legal" cases are those which seem to be substantially unrelated to current controversies over general social, economic, or political problems. While this dichotomy is an obvious oversimplification, and while there may well be disagreement in some instances as to the category in which a particular case belongs, the distinction involved is an essential one. It is not assumed, of course, that every "public policy" case will be actually decided by the judges in terms of their own policy preferences. There may be a conflict between the applicable law and the judge's preferences which he cannot reconcile in favor of the latter. ${ }^{6}$ But in any event public policy

${ }^{6}$ An extremely interesting pair of cases illustrating this point was decided during the 1942 term. These cases involved the application of state milk price control laws on sales of milk to Army camps within the states of Pennsylvania and California. In the Pennsylvania case (Penn Dairies v. Milk Control Comm. of Pennsylvania, 3I8 U.S. 26I[r943]), the state statute was held applicable, while in the California case (Pacific Coast Dairy v. Dept. of Agriculture of California, 3 I8 U.S. 285[1943]), it was not. The difference in result grew out of the fact that the camp was on government-owned land in California and so was held by the Court to constitute a federal enclave on which state laws had only a limited application, whereas in Pennsylvania the government had only leased the land. Five judges, however, did not regard this legal difference as sufficient to justify arriving at differing results in the two cases. Three of them (Douglas, Black, and Jackson) held the state-fixed prices inapplicable in both states, 
cases at least offer an opportunity for judges to vote their convictions, and the general assumption that they do so is seen in the common explanation of dissent on the Court as resulting from the clash of liberal and conservative views on public policy. It was because Professor Ganoe believed that with its present composition the Supreme Court had reached a state of "constant and continuous unanimity.... in all essential economic and political matters" that he was led to predict that "the day of major dissent has gone."7

Examination of the 75 non-unanimous opinions of the 1942 term reveals that it is possible to group 55 of them into five important "public policy" categories, namely: (I) civil liberties; (2) federal taxation; (3) business regulation; (4) federal-state conflict; and (5) workmen's compensation and bankruptcy cases. The remaining 20 non-unanimous opinions are either in the "purely legal" category, or do not lend themselves to any general public policy classification. Table 7 shows how the individual justices and the Court as a whole voted on these issues.

Civil Liberties or Bill of Rights Cases. - Ten decisions have been classified under this heading, including four which present various aspects of the freedom of religion issue raised by the activities of the Jehovah's Witnesses sect, ${ }^{8}$ five involving fundamental issues in federal trial procedure, 9 and one growing out of the government's attempt to cancel the citizenship of a naturalized Communist sympathizer. ${ }^{\text {To }}$ The strong bias of the present Court toward the protection of civil liberties is shown by the Court's favorable vote in eight of these ten cases. The only two decisions in which the contention of the government rather than that of the individual was supported by the majority of the Court were Adams v.

while the other two (Murphy and Frankfurter) considered them applicable in both cases. These five justices, then, found the law no bar to arriving at a consistent public policy, though they disagreed as to what the policy should be. The balance of power rested with the other three participating judges (Stone, Roberts, and Reed), who ruled the state laws applicable on leased land but not on owned land. They would seem to have reached this decision on "purely legal" grounds; indeed, they were lectured by Mr. Justice Frankfurter for allowing their legal interpretation to lead them to such an inconsistent public policy.

'Op. cit., p. 297 .

${ }^{8}$ Martin v. Struthers, 319 U.S. I4I (1943); Murdock v. Pennsylvania, 3 I9 U.S. 105 (I943); Jones v. Opelika (re-argument), 3 gr U.S. I03 (1943); West Virginia State Board of Education v. Barnette, 63 S.C. II 78 (1943).

9 Adams v. United States ex rel. McCann, 3 I 7 U.S. 269 (I942); United States v. Monia, 3 I 7 U.S. 424 (1943); Anderson v. United States, 3 I8 U.S. $35^{\circ}$ (I943); McNabb v. United States, 318 U.S. 332 (I943); Galloway v. United States, 319 U.S. 372 (I943).

${ }^{x}$ Schneiderman v. United States, 63 S.C. I333 (1943). 
United States ex rel. McCann, ${ }^{\mathrm{n}}$ upholding the validity of a waiver of jury trial in the federal courts by an accused person acting without the advice of counsel, and Galloway v. United States, ${ }^{\text {,2 }}$ a war risk insurance case in which the trial court's action in granting a directed verdict for the government was unsuccessfully challenged as denying the plaintiff the right of trial by jury. In both of these cases Justices Black, Douglas, and Murphy were the dissenters.

An examination of the votes of the individual justices on the civil liberties issue is very revealing. The four justices in what has previously

TABLE 7

VOTING RECORD OF THE SUPREME COURT AND INDIVIDUAL JUSTICES ON VARIOUS PUBlic POLICY ISSUES, I942 TERM

\begin{tabular}{|c|c|c|c|c|c|c|c|c|c|c|}
\hline & \multicolumn{2}{|c|}{$\begin{array}{c}\text { CIVIL } \\
\text { LIBERTIES }\end{array}$} & \multicolumn{2}{|c|}{$\begin{array}{l}\text { Federal } \\
\text { TAXation }\end{array}$} & \multicolumn{2}{|c|}{$\begin{array}{l}\text { REGULATION } \\
\text { OF BUSINESS }\end{array}$} & \multicolumn{2}{|c|}{$\begin{array}{c}\text { Federal- } \\
\text { State }\end{array}$} & \multicolumn{2}{|c|}{$\begin{array}{l}\text { Exr. CoMP. } \\
\text { AND DEBTORS }\end{array}$} \\
\hline & Gov't & Ind. & Gov't & Ind. & Gov't & Bus. & Fed. & State & For & Against \\
\hline Supreme Court. . . & 2 & 8 & 4 & 5 & I2 & 7 & 3 & $g$ & 4 & 4 \\
\hline 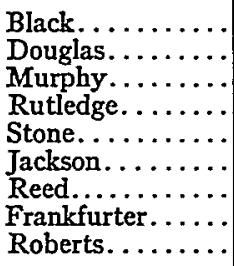 & $\begin{array}{l}0 \\
1 \\
0 \\
1 \\
3 \\
5 \\
8 \\
7 \\
7\end{array}$ & $\begin{array}{r}\text { I0 } \\
9 \\
\text { 10 } \\
5 \\
7 \\
3 \\
2 \\
3 \\
3\end{array}$ & $\begin{array}{l}7 \\
7 \\
4 \\
2 \\
3 \\
4 \\
5 \\
6 \\
1\end{array}$ & $\begin{array}{l}2 \\
2 \\
5 \\
0 \\
6 \\
5 \\
4 \\
3 \\
8\end{array}$ & $\begin{array}{r}\text { I6 } \\
\text { I6 } \\
\text { 14 } \\
7 \\
8 \\
9 \\
\text { 10 } \\
\text { 10 } \\
1\end{array}$ & $\begin{array}{r}2 \\
2 \\
3 \\
0 \\
I r \\
8 \\
9 \\
9 \\
\text { I8 }\end{array}$ & $\begin{array}{l}6 \\
5 \\
3 \\
1 \\
6 \\
2 \\
6 \\
4 \\
5\end{array}$ & $\begin{array}{r}6 \\
7 \\
9 \\
4 \\
6 \\
10 \\
6 \\
8 \\
7\end{array}$ & $\begin{array}{l}8 \\
8 \\
8 \\
3 \\
1 \\
4 \\
3 \\
3 \\
1\end{array}$ & $\begin{array}{l}0 \\
0 \\
0 \\
0 \\
7 \\
4 \\
5 \\
5 \\
6\end{array}$ \\
\hline
\end{tabular}

been called the Court's left-wing bloc are shown to be by far the most consistent supporters of civil liberties, casting 34 votes in favor of individual claims for protection of the Bill of Rights and only two against. Chief Justice Stone was the only other justice to support the individual more often than the government in this category. His strong civil liberties views were of course well dramatized in I940 by his lone vote and powerful opinion protesting the Court's decision on the compulsory flag salute in the public schools. ${ }^{13}$

Federal Taxation.- In the nine cases involving protests by federal taxpayers, the Supreme Court supported the government four times and the

\footnotetext{
Ix Supra, note 9.

I2 Supra, note 9.

${ }_{33}$ Minersville School District v. Gobitis, 3 Io U.S. 586 (x940).
} 
taxpayers five times. ${ }^{14}$ Here the pattern of division among the members of the Court was somewhat different, and more complex. The sympathy of Justices Black, Douglas, and Rutledge, which was with the individual in the preceding category, now switches to the government, and Justice Roberts, at the other end of the Court, makes an equally abrupt reversal of position. It will be noted that Justice Murphy tends to drop out of the left-wing group on this issue, while Frankfurter tends to join them.

Regulation of Business. - In this category are included 16 cases in which federal regulatory action in some form was the issue, ${ }^{15}$ and three instances of state regulatory activity. ${ }^{16}$ The Court supported business in seven cases, the government in twelve. In this field the divergence in judicial attitudes is truly remarkable, with Black and Douglas voting to uphold the regulatory action in I6 out of I8 decisions, and Roberts voting to strike it down in 18 out of $x 9$ cases. Justices Murphy and Rutledge were, along with Black and Douglas, consistent voters for the government position; in fact, Rutledge supported the government in all seven cases in which he participated. Justices Jackson, Reed, and Frankfurter all supported the government slightly more often than business, but the Chief Justice was a little on the business side of the fence. It is interesting to observe that the only two cases in which Justices Black and Douglas did not support government regulatory action both involved decisions of the Interstate Commerce Commission which were challenged as aiding the railroads at the expense of shippers and inland waterway transportation. ${ }^{17}$

${ }^{2} 4$ Helvering v. Stuart, 3 I 7 U.S. I54 (I942); Robinette v. Helvering, 318 U.S. I84 (1943); Smith v. Shaughnessy, $3 \times 8$ U.S. I 76 (x943); Helvering v. Sabine Transp. Co., 3 I8 U.S. 306 (r943); Helvering v. American Dental Co., $3^{18}$ U.S. 322 (I943); Helvering v. Griffiths, $3^{\text {I8 }}$ U.S. 37 I (I943); Helvering v. Sprouse, 3 r8 U.S. 604 (I943); Virginian Hotel Corp. v. Helvering, 63 S.C. I260 (1943); Interstate Transit Lines v. Com'r. of Internal Revenue, 63 S.C. $x 279$ (1943).

${ }^{35}$ Warren-Bradshaw Drilling Co. v. Hall, $3^{\text {I }} 7$ U.S. 88 (x942); United States v. Wayne Pump Co., 3r7 U.S. 200 (1942); Endicott Johnson Corp. v. Perkins, 317 U.S. 5or (1943); NLRB v. Indiana \& Michigan Electric Co., 318 U.S. 9 (I943); SEC v. Chenery Corp., $3^{\text {I8 }}$ U.S. 80 (I943); Overstreet v. North Shore Corporation, 3 I8 U.S. I25 (I943); Federal Security Administrator v. Quaker Oats, 318 U.S. 218 (1943); United States v. Swift \& Co., 318 U.S. 442 (1943); Institutional Investors v. Chicago, M., St. P. \& P. R. Co., 3I8 U.S. 523 (1943); Jersey Central Power \& Light Co. v. Fed. Power Comm., 3I9 U.S. 6I (I943); Barringer \& Co. v. United States, 3I9 U.S. X (I943); National Broadcasting Co. v. United States, 3I9 U.S. Igo (I943); Fed. Communications Comm. v. National Broadcasting Co., 3 I9 U.S. 239 (I943); Virginia Electric \& Power Co. v. NLRB, 63 S.C. 1214 (1943); McLeod v. Threlkeld, 63 S.C. x248 (r943); Interstate Commerce Comm. v. Inland Waterways Corp., 63 S.C. I 296 (1943).

${ }^{16}$ Public Utilities Cmsn. of Ohio v. United Fuel Gas Co., 3 I7 U.S. 456 (1943); Burford v. Sun Oil Co., 3 I9 U.S. 3 I5 (I943); Hastings v. Selby Oil \& Gas Co., $3^{\text {Ig }}$ U.S. 348 (I943).

${ }^{17}$ Barringer \& Co. v. United States, supra, note $x_{5}$; Interstate Commerce Comm. v. Inland Waterways Corp., supra, note $x_{5}$. 
Thus their votes in these two cases were quite consistent with their general position on government regulation of business, since they were here objecting to a regulatory action which they interpreted as benefiting a special interest rather than the general public interest.

Federal-State Conflicts. - In this classification have been placed all cases raising issues and conflicts between the federal and state governments. ${ }^{18}$ During the I942 term this perennial problem was presented in such forms as state taxation of Indians, who are federal wards, the applicability of state milk price control laws to milk sold to Army camps, and so on. The well-known case of Williams v. North Carolina, ${ }^{x 9}$ in which the Supreme Court held a Nevada divorce entitled to full faith and credit in other states, is included in this category though not technically a federal-state conflict, because the division of opinion on the Court was between those who were impressed with the need for a divorce system of nation-wide validity and those who considered that the individual states should have the power to set their own standards for divorce for their citizens and to make them effective.

It may come as a surprise to some that the Supreme Court voted for the state in nine of these twelve cases. However, it has been the consistent policy of the "reorganized" Court to free states from federal limitations on the exercise of their taxing and regulatory powers. The votes of the individual justices appear to have less significance in this field than in those preceding. Justices Rutledge, Jackson, Murphy, and Frankfurter are the members of the Court who upheld the state viewpoint most often.

Employees' Compensation Cases and Debtors.-In this classification are grouped six cases arising under federal or state employees' compensation laws, ${ }^{20}$ and two cases involving individual debtors under the federal

${ }_{18}$ Williams v. North Carolina, 317 U.S. 287 (1942); Davis v. Dept. of Labor of Washington, 317 U.S. 249 (1942); C. J. Hendry Co. v. Moore, 3 I8 U.S. 133 (1943); United States v. Oklahoma Gas \& Electric Co., 3I8 U.S. 206 (1943); Penn Dairies v. Milk Control Comm. of Pennsylvania, supra, note 6; Pacific Coast Dairy v. Dept. of Agriculture of California, supra, note

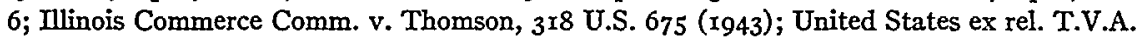
v. Powelson, 3 I9 U.S. 266 (I943); Burford v. Sun Oil Co., supra, note I6; Hastings v. Selby Oil \& Gas Co., supra, note r6; Mahnomen County v. United States, 63 S.C. 1254 (1943); Oklahoma Tax Comm. v. United States, 63 S.C. 1284 ( $(943)$. It will be noted that the Burford and Hastings cases were also classified in the business regulation category, but they raise a federal-state issue as well.

9 Supra, note 18.

${ }^{20}$ Marshall v. Pletz, 317 U.S. 383 (1943); Davis v. Dept. of Labor of Washington, supra, note I8; De Zon v. American President Lines, 318 U.S. 660 (1943); Aguilar v. Standard Oil Co. of N.J., 3I8 U.S. 724 (I943); Bailey v. Central Vermont Ry., 3I9 U.S. 350 (I943); Owens v. Union Pacific R. Co., 63 S.C. I27I (1943). It will be noted that the Davis case was also classified in the federal-state category. 
Bankruptcy Act. ${ }^{2 x}$ The Supreme Court supported the employee's claims in four of the six cases, but voted against the contentions of the bankrupt in both cases, thus achieving an even division in the eight decisions. There is a very significant division of opinion among the justices in this field. The left-wing bloc of Black, Douglas, Murphy, and Rutledge is an absolute unit on this issue, every one of their votes being cast for the employee and the debtor. Justices Roberts and Stone take the reverse position almost as decidedly. The other three justices-Jackson, Reed, and Frankfurter-occupy a middle ground.

This analysis of the five issues which were most effective in causing dissent on the Court during the 1942 term does much to clarify the alignments on that body. It shows the reason for the homogeneity of the leftwing group to be their sympathy for civil liberties, business regulation, and workmen and debtors, with somewhat less unity in the field of taxation. Roberts' position far to the right of his colleagues is explained as due principally to his views against regulation of business, and to a lesser degree by his attitude toward federal taxation, employees, and debtors. Likewise it becomes clear why the remaining four members of the Court are so hard to classify, and why the agreement relationships on the right of the Court are not particularly marked. Chief Justice Stone is to the left of this group on the civil liberties issue, but in other categories is to the right of Jackson, Reed, and Frankfurter. Mr. Justice Frankfurter agrees with Roberts on the civil liberties issue, but is far removed from him in the taxation and regulation fields. Jackson and Reed take a rather middle position, except for the former's votes in the federal-state category and the latter's views on civil liberties.

On the basis of their votes on these issues, it is easy to label five members of the Court. Clearly Justices Black, Douglas, Murphy, and Rutledge are the "liberals" of the Court, and Roberts is a "conservative." The Chief Justice also tends to act like a conservative except on the civil liberties matter. Justices Reed, Jackson, and Frankfurter fall in between, and it is largely these three justices who have upset predictions which were based on the assumption that all the New Deal appointees would react uniformly.

But in spite of their many dissents, it is clear that the present members of the Court are closer together in their fundamental political and economic thinking than was the case a few years ago. There is an obvious

2x State Bank of Hardinsburg v. Brown, 3I7 U.S. I35 (I942); Harris v. Zion's Savings Bank \& Trust Co., 317 U.S. 447 (I943). There were three other non-unanimous cases arising under the Bankruptcy Act, but they involved corporations rather than individuals. 
difference between the moderate Roberts, farthest right today, and the hard-shelled conservatives of the I930's, McReynolds and Butler. This difference can be demonstrated mathematically. During the 1938 term the percentage agreement between McReynolds and the Black-Douglas team was exactly zero. They were on opposite sides in every disputed decision, whereas during the 1942 term Roberts was in agreement with Black and Douglas almost 30 per cent of the time.

But if the justices are basically closer together in their views, why should the rate of dissent be increasing so sharply? Perhaps one answer is that battle lines which were maintained fairly rigidly when there was organized and rather equal conservative-liberal opposition have degenerated into guerrilla warfare now that the major battle has been won by the liberals. Perhaps it is that the judges, having drawn closer together on fundamentals, are freer to argue over details, disputing more as lawyers and less as philosophers. Perhaps it is that since the old rules have been overthrown in so many fields, there is natural uncertainty while the new ones are being worked out.

The old dissent has passed because the old issues have passed. In their places are new issues-and new dissents. But the underlying problem remains the same-maintaining a balance between the guarantees of individual freedom and the grant of governmental powers adequate for social well-being. This analysis of alignments on the Supreme Court during the 1942 term certainly demonstrates a range of attitudes on the part of the present membership sufficiently broad to guarantee effective performance by the Court of its historic function. 